\title{
Processing of One-Chain to Two-Chain Renin in the Mouse Submandibular Gland is Influenced by Androgen
}

\author{
JULIE R. INGELFINGER, RICHARD E. PRATT, TIMOTHY P. ROTH, AND VICTOR J. DZAU \\ Molecular and Cellular Vascular Research Laboratory, Division of Vascular Medicine and Atherosclerosis, \\ Brigham and Women's Hospital [J.R.I, R.E.P., T.P.R., V.J.D.J, and Division of Nephrology [J.R.IJ, The \\ Children's Hospital, Harvard Medical School, [J.R.I, R.E.P., T.P.R., V.J.D.],Boston, Massachusetts 02115
}

\begin{abstract}
In the male CD-1 mouse submandibular gland (SMG) renin activity increases markedly with puberty. We have reported that this is, in part, due to an androgen-mediated increase in renin gene transcription. In this study, we examined whether posttranslational processing is also influenced by androgen. We studied secretion and processing of active renin in the $\mathrm{CD}-1$ male mouse SMG which secretes primarily the Ren-2 renin isozyme before and after puberty and also compared findings with the adult female CD-1 mouse. Maturation increases renin level and secretion rate in the male SMG but much less in the female, In addition, Western blot analysis of molecular forms of renin in SMG tissue and media shows a predominance of 1-chain intermediate form of renin before puberty but of the 2-chain mature form thereafter. Adult female SMG contains and secretes much less active renin than the male organ. Administration of testosterone to the female CD-1 mouse induces an adult male level and pattern of secretion, with high concentrations of active 2-chain renin being secreted. These data suggest that SMG renin is androgen regulated, in part by an androgen-responsive enzyme that processes 1-chain renin to the 2-chain form. (Pediatr Res 25:332-335, 1989)
\end{abstract}

Abbreviation

SMG, submandibular gland

The sequence and kinetics of biosynthetic processing of SMG renin have been described in the mature male mouse or testosterone-treated female mouse of the 2-gene strains $(1-4)$. Prorenin is rapidly cleaved to a single chain intermediate which is subsequently processed to the mature 2-chain form of renin. Both 1and 2-chain forms are secreted, the 1-chain form being six times more active than the 2-chain (2). Thus, more than one form of active renin is secreted. Our previous study also suggested two separate pathways of renin secretion-a constitutive pathway from the Golgi consisting of only 1-chain renin, and a regulated pathway via secretory granules through which predominantly 2chain renin is secreted $(1,5)$. We and others have shown that renin levels increase with age in the SMG (6-8). Furthermore,

Reccived April 29. 1988: accepted November 15, 1988.

Correspondence and reprints Dr. Julie R. Ingelfinger and Dr. Victor J. Dzau, Division of Vascular Medicine and Atherosclerosis, Brigham and Women's Hospital, 75 Francis Strect. Boston, MA 02115.

Supported by NIH Grants HL35610, HL35792, HL19259, HL35252, NIH Specialized Center of Research in Hypertension HL33697, the Milton Fund, and a grant from RJR Nabisco. Inc. J.R.I. was the recipient of NIH Senior Fellowship HL06913. V.J.D is an established investigator of the American Heart Association. we have demonstrated that the rate of secretion of SMG renin increases with puberty. We have demonstrated that the increase in content and secretion of renin by the male SMG at puberty is, in part, due to an increase in renin transcriptional rate. In the present study, we examined whether the processing of 1-chain renin (the intermediate form) to the 2-chain renin (the mature enzyme) in the CD-1 male SMG is influenced by growth and development. We studied further whether androgen is responsible for this effect.

\section{MATERIALS AND METHODS}

Animals. Outbred Swiss [Crl:CD-1(1CR)BR] male and female mice were studied from the ages of 25 to $40 \mathrm{~d}$. Pregnant female mice were originally purchased from Charles River Breeding Laboratories (Wilmington, MA). Subsequently, we established our own colony. Where indicated, testosterone propionate was administered daily by subcutaneous injection of $1 \mathrm{mg}$ in $0.1 \mathrm{~mL}$ polyethylene glycol-400 $(4,8)$. Animals had free access to food and water and were kept in alternating 12-h cycles of light and dark. Animals were weaned at $21 \mathrm{~d}$. Before that, they were kept in litters of 8-10 animals.

Animals were killed by cervical dislocation. Kidneys and SMG were rapidly removed and dissected and then finely minced on ice at $4^{\circ} \mathrm{C}$ for secretion experiments as described below.

Secretion experiments. SMG or kidneys from male or female CD-1 mice (ages $25-40$ d) were minced at $4^{\circ} \mathrm{C}$ in RPMI 1640 medium that had previously been gassed with $95 \% \mathrm{O}_{2}, 5 \% \mathrm{CO}_{2}$ (9). After being washed four times in RPMI 1640 medium, the tissue was preincubated for $40 \mathrm{~min}$ at $37^{\circ} \mathrm{C}$ and then rewashed twice to remove plasma as well as products of cell lysis. The amount of SMG tissue was $1 \mathrm{SMG} / 3 \mathrm{~mL}$ medium for ages $\geq 30$ $\mathrm{d}$, and $2-3 \mathrm{SMG} / 3 \mathrm{ml}$ medium at younger ages. The amount of kidney tissue was 2 kidneys $/ 5 \mathrm{~mL}$ media. The secretion experiments were then carried out over the next $60 \mathrm{~min}$ at $37^{\circ} \mathrm{C}$, with samples of media removed for analysis at $0,20,40$, and $60 \mathrm{~min}$. Medium and tissue were placed on ice and proteinase inhibitors [0.5 mM EDTA, $0.5 \mathrm{mM}$ sodium tetrathionate (NaTT), and $0.02 \mathrm{mM}$ phenylmethylsulfonyl fluoride (PMSF)] were added to the medium. Tissue was homogenized with a sonicator in $0.1 \mathrm{M}$ Tris- $\mathrm{HCl}, \mathrm{pH} 74$, with protease inhibitors as above plus $0.25 \%$ $(\mathrm{v} / \mathrm{v})$ Triton $\mathrm{X}-100$. This mixture of protease inhibitors has been shown to be effective in maintaining renin stability and in prevention of nonspecific breakdown. Samples of media at various time points and of tissue were assayed for renin (10) and for protein, using the method of Bradford (Bio-Rad Laboratories, Richmond, CA) (11). Lactate dehydrogenase assays were performed on the tissue and media in parallel experiments to demonstrate that renin release is not due to cell death or lysis (12). In addition Western blots (as described below) were performed (13). 
The protocols used included: 1) male SMG secretion at 25 , 30,35 , and 40 (adult) d of age; 2) female adult (40-d) SMG secretion studies in mice that had been given testosterone propionate $1 \mathrm{mg} / \mathrm{d}$ subcutaneously (experimental group) or vehicle alone (control group)

Renin concentration assay. Media was assayed for renin concentration (10) after dilution in $0.1 \mathrm{M}$ Tris- $\mathrm{HCl}, \mathrm{pH} 7.4$, with 1 $\mathrm{mg} / \mathrm{ml} \mathrm{BSA}$ and proteinase inhibitors (EDTA, $0.5 \mathrm{mM}, 0.5 \mathrm{mM}$ NaTT, and $0.02 \mathrm{mM}$ PMSF). Tissue was homogenized, and after gently rocking for 2-3 min, homogenates were centrifuged at $3000 \times \mathrm{g}$ for $5 \mathrm{~min}$, and supernatants were assayed. Plasma from nephrectomized sheep having no detectable renin activity was used as the source of renin substrate. The concentration of substrate in the sheep anephric plasma was greater than $1000 \mathrm{ng}$ of angiotensin I equivalent $/ \mathrm{mL}$, and the amount of substrate cleaved during reaction was always less than 5\%. Reaction mixtures contained the angiotensinase inhibitors 8-hydroxyquinolone $(5 \mathrm{mM})$ and 2,3 dimercapto-1-propanol $(1.6 \mathrm{mM})$ in $0.1 /$ $\mathrm{M}$ Tris $\mathrm{HCl}, \mathrm{pH}$ 7.4. The angiotensin I release was quantitated by RIA as described (10)

Western blot analysis of renin molecular forms (excluding prorenin). Western blot analysis was prepared as follows (11): Tissue was homogenized in $0.1 \mathrm{M}$ Tris- $\mathrm{HCl}, \mathrm{pH} 7.4$, with inhibitors as mentioned above. To purify and concentrate active renin partially, homogenate was subjected to ammonium sulphate precipitation and chromatography on pepstatin conjugated to aminohexyl-sepharose (which binds only the active renin) (2, 14). After elution with SDS-sample buffer, the material containing active renin was subjected to SDS-PAGE, under reducing conditions with $\beta$-mercaptoethanol (2). Reduction with mercaptoethanol allows separation of 1-chain $\left(\mathrm{M}_{\mathrm{r}} 37000\right)$ from 2-chain renin during SDS-PAGE, as the latter will migrate as heavy chain $\left(\mathrm{M}_{\mathrm{r}} 32000\right)(2)$, which is easily detected and distinct from the 1chain renin. After electrophoresis, each gel was subjected to electrophoretic transfer to nitrocellulose sheets. Blots were reacted with rabbit antimouse renin-specific antiserum (1:250 dilution), followed by ${ }^{125}$ I-labeled goat antirabbit antiserum (New England Nuclear, Boston, MA) $10^{6}$ to $10^{7} \mathrm{cpm} / \mathrm{blot}$. After being washed, blots were autoradiographed, and renin species of different mol wt were quantitated by densitometry.

\section{RESULTS}

The renin enzymatic levels in the male SMG increased with age, from $2.8 \times 10^{3} \mathrm{ng}$ angiotensin $\mathrm{I} / \mathrm{mg}$ tissue protein $/ \mathrm{h}$ at $\mathrm{d} 3$ $(n=7)$ to $1.0 \times 10^{6} \mathrm{ng}$ angiotensin $\mathrm{I} / \mathrm{mg}$ tissue protein $/ \mathrm{h}$ at $\mathrm{d}$ $40(n=13)$ (Table 1). Secretion experiments showed that both amount and rate of active renin secretion from male SMG rose with age parallel to the increase in tissue levels (from $<1 \mathrm{ng}$ angiotensin $\mathrm{I} / \mathrm{h} / \mathrm{mg}$ protein $/ \mathrm{min}$ at $\mathrm{d} 20(n=6)$ to $1.8 \times 10^{4}$ angiotensin $\mathrm{I} / \mathrm{h} / \mathrm{mg}$ protein $/ \mathrm{min}$ at $\mathrm{d} 40(n=16), p<0.001)$ (Table 1 ). Less than $1 \%$ of tissue lactate dehydrogenase activity was found in media at $30 \mathrm{~min}$ and at the conclusion of secretion experiments, whereas active renin secretion rate increased linearly with time. As less than $1 \%$ of cytosolic lactate dehydrogen- ase appears in the media, the renin release seen is not due to cell death or lysis.

Western blot analysis of homogenates from the SMG of male mouse showed increasing amounts of 2-chain renin with maturation of the animal. This pattern was seen both in the SMG tissue and in media into which renin was secreted (Fig. 1). The proportion of 1-chain as compared to 2-chain renin in the SMG varied with age. To quantitate this, we performed densitometry on the 1-chain and the 2-chain renin bands and expressed the results as percentage of 1-chain or 2-chain renin of total active renin $(1 c+2 c$ renins as $100 \%)$. Our data showed that the percentage of 1-chain renin of total active renin in the tissue was $66.7 \pm 5$ at $\mathrm{d} 25 ; 42.9 \pm 2.7$ at $\mathrm{d} 30 ;$ and $17.6 \pm 3.3$ at $\mathrm{d} 40(n$ $=12$ studies). The percentage of 1 -chain renin in media was 25 $\pm 2 \%$ at $\mathrm{d} 30$ (prepuberty), whereas it was $11.1 \pm 3 \%$ at $\mathrm{d} 40$ (maturity). These findings were highly reproducible $(n=12$ studies). Western blots of active renin forms were also performed in female mice treated with testosterone propionate, $0.1 \mathrm{mg}$ subcutaneously for 7,10 , and $14 \mathrm{~d}$. Control adult females were also studied, and showed very little secretion of salivary gland renin $(16.7 \mathrm{ng}$ angiotensin $\mathrm{I} / \mathrm{h} / \mathrm{mg}$ protein $/ \mathrm{min}$ ). Testosterone induced a high level of secretion of salivary gland renin $\left(3 \times 10^{3}\right.$ ng angiotensin $\mathrm{I} / \mathrm{h} / \mathrm{mg}$ protein $/ \mathrm{min}$. Because of the low level of renin secreted by the control (untreated) female SMG, the ratio of 1-chain to 2-chain renin could not be accurately evaluated in the Western blot experiments in untreated females (Fig. 2). However, as may be seen, a pattern similar to that in the mature male was induced in females treated with testosterone.

\section{DISCUSSION}

This investigation was designed to study the regulation of SMG renin content and secretion rate and processing in the CD1 mouse during ontogeny. Renin enzyme levels in SMG increase greatly with onset of puberty in an androgen-dependent manner $(3,4,6)$. The present study suggests that there are also changes in the biosynthetic processing of active renin in the SMG during ontogeny, with a relative increase in 2-chain renin in the mature male animal. The relative amounts of 1 -chain and 2 -chain renin might be thought to account in part for the increase in male SMG renin enzyme activity. However, 2-chain renin has less activity than does 1-chain (1), yet renin activity is increasing with age in the mouse at the time 2-chain renin is increasing, so such a shift in ratio cannot be a factor in increasing renin activity levels. By deduction, these data suggest that the overall synthesis and storage of renin must be greatly increased in the male mouse SMG during ontogeny. Indeed, this has been shown to be the case $(3,4)$. The changes in the ratio of 1 -chain renin to 2 -chain renin with age have several possible implications. One possibility is that before puberty, male SMG synthesizes principally 1-chain renin which is not stored but secreted via a constitutive pathway. After puberty, the granular convoluted tubule cells in which renin is produced become larger and contain more rough endoplasmic reticulum, free ribosomes, and electron-dense secretion granules (15). We postulate that with maturational cytodifferen-

Table 1 . Tissue renin activity and renin secretion rate in mice at various ages

\begin{tabular}{lcccc}
\hline & \multicolumn{3}{c}{ Age $(\mathrm{d})$} \\
\cline { 2 - 5 } & $20-25$ & $30-32$ & 35 & 40 \\
\hline Tissue renin activity* & $2.8 \pm 0.42 \times 10^{3}$ & $0.4 \pm 0.14 \times 10^{6}$ & $2.0 \pm 0.16 \times 10^{6}$ & $1.8 \pm 0.4 \times 10^{6}$ \\
$n$ & 7 & 9 & 7 & 13 \\
Secretion ratet & $<1$ & $4 \pm 1.6 \times 10^{2}$ & $1.6 \pm 0.3 \times 10^{3}$ & $1.8 \pm 0.5 \times 10^{4}$ \\
$n$ & 6 & 11 & 11 & 11
\end{tabular}

\footnotetext{
* Renin activity is expressed as ng angiotensin $\mathrm{I} / \mathrm{h} / \mathrm{mg}$ protein, mean \pm SEM. For each age group, number of experiments $(n)$ is listed below the
} renin activity value. ANOVA, $p<0.0001$

+ Secretion of active renin, evaluated/min, is expressed as $\mathrm{ng}$ angiotensin $\mathrm{I} / \mathrm{h} / \mathrm{mg}$ tissue protein/min. Number of experiments $(n)$ is listed below the secretion rate for each age studied. ANOVA, $p<0.001$ 


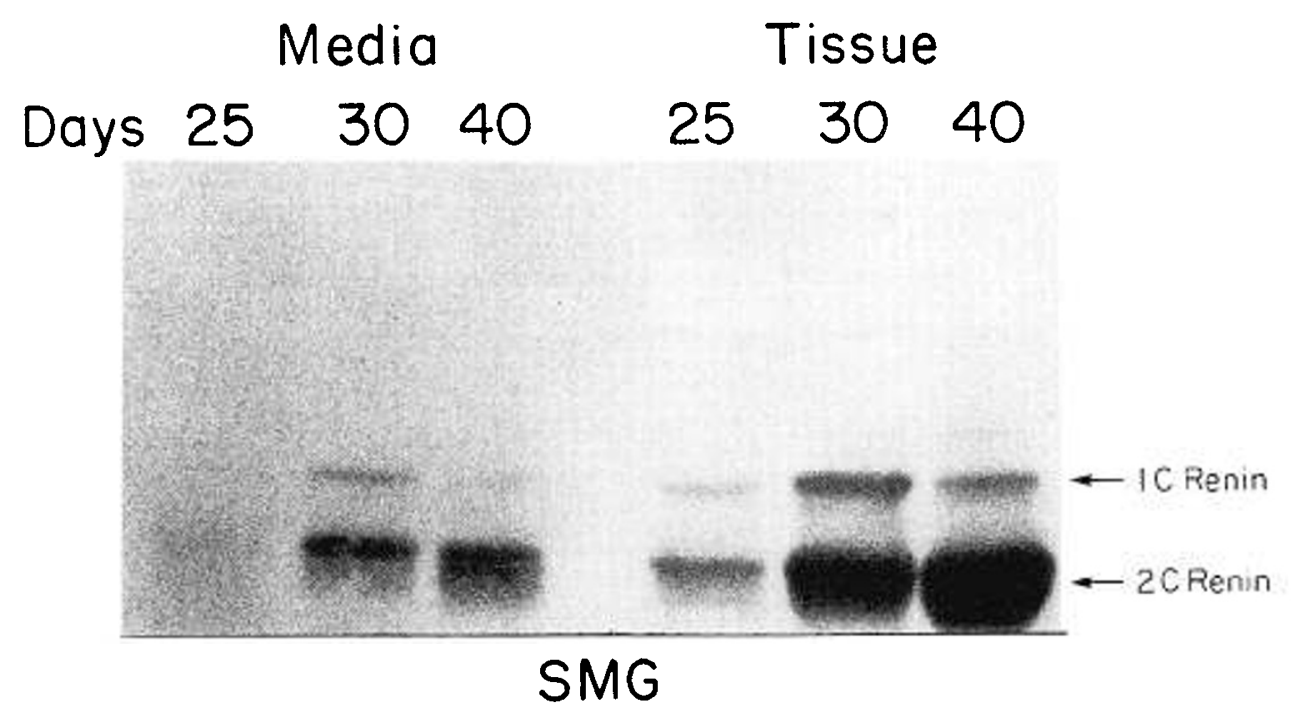

Fig. 1. A representative Western blot analysis of active renin secreted into media or present in tissue from male mice at various ages $(25,30,40$ d). Prepared samples (5000 $\mathrm{ng}$ angiotensin I equivalent) were electrophoresed as described (2), and reacted first with rabbit antimouse-specific renin antibody and subsequently with goat antirabbit $\operatorname{IgG}{ }^{125} \mathrm{I}$ and autoradiogrammed. Amounts of 1 -chain and 2-chain renins increased, with a relatively greater increase of the latter in male SMG in both media and tissue with increasing age (see text for quantitation).

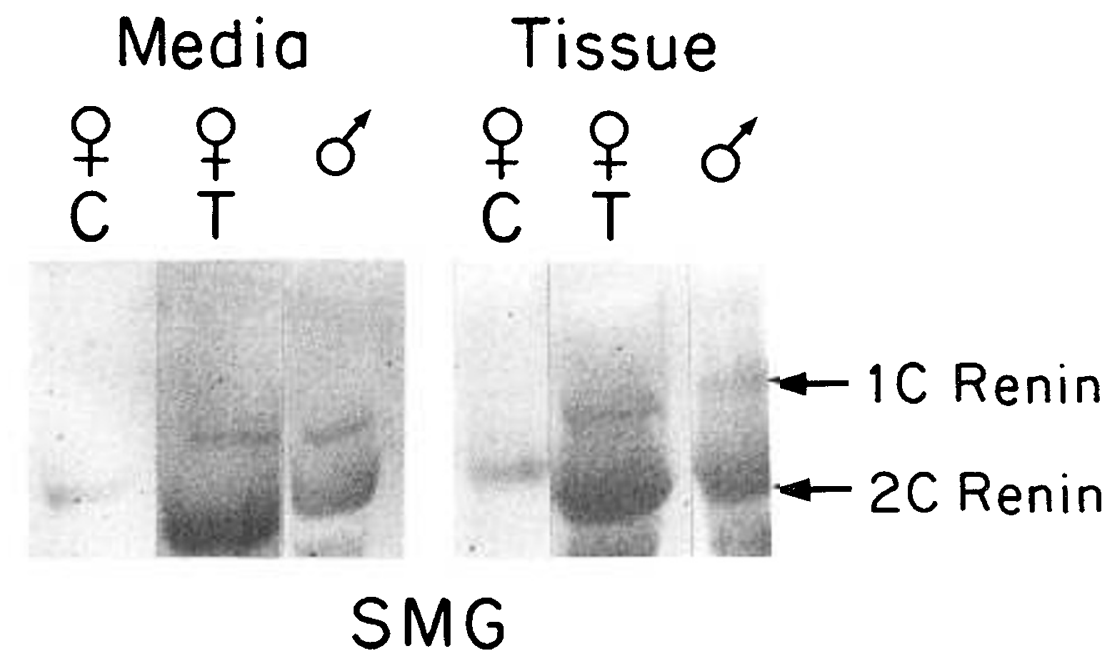

Fig. 2. A representative Western blot analysis of active renin secreted by adult female SMG tissue into media. Prepared samples from SMG of control female or from female mice treated with testosterone propionate $(1 \mathrm{mg} / \mathrm{d})$ were eletrophoresed, transferred to nitrocellulose paper, and reacted with rabbit antimouse-specific renin antibody. Subsequently, samples were reacted with goat antirabbit ${ }^{125} \mathrm{I} \operatorname{IgG}$ and autoradiogrammed. Little can be secn for control adult female. Adult females treated with testosterone display a male pattern.

tiation, change in cellular processing occurs, resulting in increased synthesis and storage of renin in the 2-chain form after puberty. Indeed, studies by Gresik et al. (16) have shown increase in immunocytochemical localization (and therefore storage) of renin to granular convoluted tubules of the SMG after puberty.

The increase in SMG 2-chain renin might also reflect a hormonally dependent step in renin maturation. One possibility is that an androgen-sensitive processing enzyme might become activated with the onset of puberty of the male mouse. Multiple polypeptides in SMG, in addition to renin, are regulated by androgen $(17,18)$. One such polypeptide, e.g. an arginine esterase that also increases in the male SMG with puberty, has the ability to process prorenin to renin in vitro (18). We speculate that such an enzyme may cleave the internal dipeptide (Arg-Arg), converting 1-chain to 2-chain renin. Other hormones besides androgen are known to influence the synthesis rate of SMG proteins, such as nerve growth factor, epidermal growth factor, or the abovementioned esterase $(17,18)$. Epidermal growth factor and nerve growth factor are produced in the same cells of the $\mathrm{SMG}$ as renin $(15,18)$, and their apparent synthesis may be affected by levels of thyroid hormone, corticosterone, and estrogen as well as by androgen (19). However, the peak plasma levels of thyroid hormone, estrogen, or corticosterone during ontogeny in the mouse do not coincide with either the time course of apparent increase in renin synthesis or with change in relative amounts of 1 -chain and 2-chain renin. During ontogeny in the mouse, growth hormone levels and prolactin levels also vary. However, these hormones have not been evaluated with respect to their possible influence on SMG protein production (20), though levels of neither growth hormone nor prolactin peak or change at the times when renin production by SMG changes (20). Thus, by inference, androgen remains the most likely candidate hormone affecting renin processing during ontogeny. Our additional data show more definitely that androgen influences renin processing, as testosterone administration to female mice induces a male rate and pattern of SMG renin secretion. In high-renin-producing strains of mice, such as CD-1, which contain both the Ren-1 and Ren-2 genes encoding for renin, it has been suggested that Ren2 expression appears to be influenced by hormonal milieu (3, 17). The results of the present study support this concept. 
In summary, these data demonstrate that SMG renin expression and processing changes during growth and development. A major factor involved in the change in SMG renin processing is androgen. Further developmental studies will be required to examine this concept in more detail.

Acknowledgments. The authors thank Ms. Donna MacDonald and Ms. Nancy Beatty for secretarial assistance.

\section{REFERENCES}

1. Pratt RE, Dzau VJ 1984 Purification and characterization of one-chain and two-chain renins from mouse submandibular gland. Hypertension 6 (suppl I): I-101-I-105

2. Pratt RE, Ouellette AJ, Dzau VJ 1983 Biosynthesis of renin: multiplicity of active and intemediate forms. Proc Natl Sci USA 80:6809-6813

3. Pratt RE, Dzau VJ, Oucllette AJ 1984 Influence of androgen on translatable renin $\mathrm{mRNA}$ in the mouse submandibular gland. Hypertension 6:605-613

4. Pratt RE, Dzau VJ, Oucllette AJ 1981 Abundant androgen regulated mRNAs in mouse submandibular gland: cell-free translation of mouse precursor mRNA. Nucleic Acids Res 9:3433-3449

5. Pratt RE, Roth TP, Dzau VJ 1984 Evidence for two pathways of renin sccretion. Circulation 70:II-315 (abstr) (Am Heart Assoc Monogr 107)

6. Ingelfinger JR, Pratt RE, Dzau VJ. 1988 Regulation of extra-renal renin during ontogeny. Endocrinology 122:782-786

7. Ingelfinger JR, Pratt RE, Ellison KE, Dzau VJ 1985 Regulation of mouse renin expression during ontogeny. Pediatr Res 19 (suppl): 156(abstr)

8. Wilson CM, Cherry M, Taylor BA, Wilson JD 1981 Genetic and endocrine control of renin activity in submaxillary gland of the mouse. Biochem Genet 19:509-523
9. Moore GE, Gerner RE, Franklin HA 1967 Culture of normal human leukocytes JAMA 199:519-524

10. Haber E, Koerner T, Page LB, Kliman B, Purnode A 1969 Application of a radioimmunoassay in angiotensin I to the physiologic measurement of plasma renin activity in normal human subjects. $\mathcal{J}$ Clin Endocrinol Metab 2:1349-1355

11. Bradford MM 1976 A rapid and sensitive method for the quantitation of microorganism quantities of protein utilizing the principles of protein-dye binding. Ann Biochem 72:248-254

12. Wroblewski F, LaDue JS 1955 Lactic dehydrogenase activity in blood. Proc Soc Exp Biol Med 90:210-213

13. Towbin H, Staehelin T, Gordon J 1979 Electrophoretic transfer of proteins from polyacrylamide gels to nitrocellulose sheets: procedure and some ap plication. Proc Natl Acad Sci USA 76:4350-4354

14. Chang J-J, Kisaragi M, Okamoto $\mathrm{H}$, Inagami $\mathrm{T} 1981$ Isolation and activation of inactive renin from human kidney and plasma. Hypertension 3:509-515

15. Gresik EW, McRae EK 1975 Postnatal development of mouse submandibular gland. Cell Tiss Res 157:411-412

16. Gresik EW, Michelakis A, Barka T. 1978 Immunocytochemical localization of renin in the submandibular gland of the mouse during postnatal development. Am J Anat 153:443-450

17. Wilson CM, Myhre MJ, Reynolds RC, Wilson JC 1982 Regulation of mouse submaxillary gland renin by thyroxine. Endocrinology 110:982-989

18. Barka T 1980 Biologically active polypeptides in submandibular gland. J Histochem Cytochem 28:836-839

19. Waler P. Weichsel Jr. ME, Eveleth D, Fisher DA 1980 Ontogenesis of nerve growth factor in submaxillary glands and nerve growth factor in brains of immature micc: correlation with ontogenesis of serum levels of thyroid hormones. Pediatr Res 16:520-524

20. Slabaugh B, Licbermann ME, Rutledge JJ, Gorski J 1982 Ontogeny of growth hormone and prolactin gene expression in mice. Endocrinology 110:14891497 